\title{
Report on the \\ XXXIV International ASTIN Colloquium, August 24-27, 2003, Berlin
}

The $34^{\text {th }}$ International ASTIN Colloquium 2003 was held in Berlin from August 24 to 27 . More than 300 participants from 34 countries all over the world made it an extremely successful event. Opening addresses were given by Edward Levay and W. James MacGinnitie for the ASTIN Committee, and Elmar Helten, Dieter Köhnlein and Christian Hipp for the local Organizing and Scientific Committee. In contrast to its predecessors, no parallel sessions for presentations were planned this time. Instead, Poster Sessions were organized which offered ample opportunity to the participants for scientific exchange with the authors during extended coffee breaks. This new concept was very much welcomed by the attendants and will most probably be maintained also in future ASTIN conferences.

Social events were a visit to "TIPI - the tent", a varieté show on the evening of the first conference day, a boat trip on the Wannsee on the second day and a closing gala dinner at the post museum in the evening of the final day.

The topics of the invited speakers for this year's Colloquium focused on two major theme groups, one of which was the ongoing and deepening interplay between financial and insurance markets (key words: Financial Risk Management, Securitization, Loss Reserving, Solvency Standards). The second one was devoted to the possible consequences of modern medical genetic research for life and health insurance.

The opening plenary lecture was given by Paul Embrechts (ETH Zürich) on the topic "Insurance analytics: actuarial tools for financial risk management". A key message within this very comprehensive and refreshing survey over recent developments in this area was "actuarial thinking", in particular in connection with financial risk management. As new challenges for actuaries due to regulatory measures in the spirit of Basel I and II were mentioned: premium principles and risk measures - pricing in incomplete markets - stress- and solvency-testing - dynamic financial analysis (DFA) - stochastic dependence structures "beyond the normal distribution" (key word: copulas).

The following presentation of David Mocklow (Chicago) was devoted to the topic "Risk Linked Securities: what's shaking?". Seen from the perspective of a reinsurer, a thorough survey over different products and markets related to ART was given, with a particular emphasis on natural catastrophes and the "value of securitization".

The lecture of Greg Taylor (Sydney and University of Melbourne) closed the plenary lecture of the first day. It was dealing with "Loss reserving techniques: past, present and future". In his lecture, he presented a hierarchical approach to classifying the various known loss reserving techniques, differentiating between macroscopic vs. microscopic models, stochastic vs. deterministic 
models and models with and without dependence structures. An in-depthanalysis was made for adaptive approaches including Kalman filtering, a technique which is well-known in the area of generalized linear models (GLM).

The second day of the colloquium started with a survey lecture of Søren Asmussen (Aarhus University) on "Some applications of phase-type distributions to insurance and finance". After some introductory remarks on historic developments and fundamental properties of phase-type distributions emphasis was put on the advantages of a rigorous application of matrix calculus in this field. This simplifies not only a lot the classical proofs, but allows also for new results in an elegant way, in particular in ruin theory with a finite time horizon, or for pricing of Russian options.

The subsequent two lectures were devoted to the medical topics outlined above. Jean Lemaire (Wharton School, Philadelphia) and Angus MacDonald (Heriot-Watt University, Edinburgh) shared their presentation on "Genetics, family history, and insurance underwriting: an expensive combination?". A major problem in this context is the question whether life or health insurance companies have the right to use or obtain information on the genetic code of a client in order to fix a risk-adjusted premium. From a legal point of view, this problem is dealt with in very different ways even within Europe, not to speak of the rest of the world. Besides this aspect, it was pointed out that also from the medical perspective, statistically significant prognoses on a possible outbreak of diseases related to gene defects are dubious, in particular if multi-factorial gene disorders have to be considered. Family history is another source of information that can lead to different conclusions here.

These statements were strongly supported by Jens Reich (Humboldt-Universität Berlin) with his lecture on "Living is a risky endeavour - less so through genetic medicine?". The audience was informed in detail about the biological foundations of the human genome and various aspects of "cloning". Special emphasis was given to the legal problems with stem cell research in particular in Germany, where such topics are still discussed in a quite controversial way.

The closing plenary lecture of the last day was presented by Harry Panjer (University of Waterloo, Canada) with the title "Development of international insurance company solvency standards", finding thus a way back to the topic of the opening lecture of the first day. Perspectives for future actuarial activities especially for the development and unification of tools for regulatory authorities were outlined, such as risk measures and their properties (VaR, coherent risk measures, TailVaR), stochastic modeling of dependencies by copulas and an improvement of the "covariance formula" for the valuation of risk based capital (RBC).

Besides the plenary lectures, various other contributions were organized in working sessions. In the order of presentations, these were:

- Techniques for valuation a general insurance company within the framework of IAS standards: some proposals (by Aurélie Despeyroux, Charles Levi, Christian Partrat and Jerôme Vignancour)

- Asbestos: The current situation in Europe (by Laura Salvatori, Alessandro Santoni and Darren Michaels) 
- Munich Chain Ladder - Closing the gap between paid and incurred IBNRestimates (by Gerhard Quarg, with an additional comment by Thomas Mack)

- Capital and Asset Allocation (by René Schnieper)

- Stochastic orders in dynamic reinsurance markets (by Thomas Møller)

- Risk Exchange with distorted probabilities (by Andreas Tsanakas)

- Multidimensional Credibility applied to estimating the frequency of big claims (by Hans Bühlmann, Alois Gisler and Denise Kollöffel)

- Credibility weighted hazard estimation (by Jens Perch Nielsen and Bjørn Lunding Sandqvist)

- Marketing and Bonus-Malus Systems (by Sandra Pitrebois, Michel Denuit and Jean-Francois Walhin)

- Insurance applications of near-extremes (by Enkelejd Hashorva and Jürg Hüsler)

- Windstorm claims dependence and copulas (by Olivier Belguise and Charles Levi)

- Tail distribution and dependence measures (by Arthur Charpentier)

- Robust inference in rating models (by Gilles Dupin, Alain Monfort and JeanPierre Verle)

- Basis risk and cat risk management (by Frank Krieter)

- Copula: A new vision for economic capital and application to a four line of business company (by Fabien Faivre)

- Effets de la dépendance entre différentes branches sur le calcul des provisions (by Antonin Gillet and Benjamin Serra)

- Modeling and generating dependent risk processes for IRM and DFA (by Dietmar Pfeifer and Johana Neslehová)

- Capital allocation survey with commentary (by Gary G. Venter).

Poster contributions were (in alphabetical order of the authors):

- Fair Value of Life Liabilities with Embedded Options: An Application to a Portfolio of Italian Insurance Policies (by Giulia Andreatta and Stefano Corradin)

- A Comparison of Strategic Reinsurance Programs (SRP) with Banking Activities and Other Insurance and Reinsurance Activities (by Baruch Berliner)

- Dynamic Asset Liability Management: A Profit Testing Model for Swiss Pension Funds (by Ljudmila Bertschi, Sven Ebeling and Andreas Reichlin)

- Economic Risk Capital and Reinsurance: An Extreme Value Theory's Application to Fire Claims of an Insurance Company (by Stefano Corradin)

- On the Distribution of the Deficit at Ruin and the Surplus Prior to Ruin in the Compound Binomial Model (by Esther Frostig)

- The Impact of Statistical Dependence on Multiple Life Insurance Programs (by Esther Frostig and Benny Levikson)

- Optimal Dividend Payment under a Ruin Constraint: Discrete Time and State Space (by Christian Hipp)

- The Impact of Reinsurance on the Cost of Capital (by Werner Hürlimann)

- Optimality of a Stop-Loss Reinsurance in Layers by Werner Hürlimann) 
- The Czeledin Distribution Function (by Markus Knecht and Stefan Küttel)

- On the Loading of Largest Claims Reinsurance Covers (by Erhard Kremer)

- Exposure Rating in Liability Reinsurance (by Thomas Mack and Michael Fackler)

- Credibility Evaluation for Heterogeneous Populations (by Udi E. Makov)

- On a Non-Linear Dynamic Solvency Control Model (by Vsevolod Malinovskii)

- Capital Consumption: An Alternative Methodology for Pricing Reinsurance (by Donald Mango)

- A Stochastic Control Model for Individual Asset-Liability Management (by Sachi Purcal)

- On Error Bounds for the Approximation of Random Sums (by Bero Roos and Dietmar Pfeifer)

- A Risk Charge Calculation Based on Conditional Probability (by David Ruhm and Donald Mango)

- Conditional Risk Charge Demo using DFAIC (by David Ruhm and Donald Mango)

- A Risk Theoretical Model for Assessing the Solvency Profile of a General Insurer (by Nino Savelli)

- On Unknown Accumulations in Accident Insurance: An Upper Bound of the Expected Excess Claim (by Hans Schmitter)

- Actuarial Principles of the Cotton Insurance in Uzbekistan (by Bakhodir Shamsuddinov)

- The Estimation of Market VaR using Garch Models and Heavy Tail Distributions (by Ricardo A. Tagliafichi)

- Fit to a $\mathrm{t}$ - Estimation, Application and Limitations of the t-Copula (by Gary G. Venter)

- Une Nouvelle Caractérisation de la Distribution de Pareto, avec Application à la Cadence de Paiement du Réassureur en Excédent de Sinistre (by JeanFrancois Walhin).

The closing ceremony of the Colloquium was performed by Edward Levay and Dieter Köhnlein.

All presentations (invited lectures, working papers and posters) can be downloaded from the Colloquium website at www.astin2003.de.

Dietmar Pfeifer 